\title{
Priorities of Fair Globalization
}

\author{
Leif Bloch Rasmussen, Viktoria Skarler \\ Institute of Informatics, Business Copenhagen School \\ lbr.inf@cbs.dk, www.cbs.dk/staff/leif_bloch_rasmussen
}

The report, A Fair Globalization: Creating opportunities for all, by the World Commission on the Social Dimension of Globalization (ILO), seek a process of globalization with a strong social dimension based on universally shared values, respect for human rights and individual dignity. A world that is fair, inclusive, democratically governed and gives opportunities and tangible benefits for all countries and people in the world. To this end the report calls for:

- A focus on people. The cornerstone of a fairer globalization lies in meeting the demands of all people for: respect for their rights, cultural identity and autonomy; decent work: and the empowerment of the local communities they live in. Gender equality is essential.

- A democratic and effective State. The State must have the capability to manage integration into the global economy, and provide social and economic opportunity and security.

- Sustainable development. The quest for a fair globalization must be undertaken by the interdependent and environmental protection at the local, national, regional and global levels.

- Productive and equitable markets. This requires sound institutions to promote opportunity and enterprise in well-functioning market economy.

- Fair rules. The rules of the global economy must offer equitable opportunity and access for all countries and recognise the diversity in national capacities and developmental needs.

- Globalization with solidarity. There is a shared responsibility to assist countries and people excluded from or disadvantaged by globalization. Globalization must help to overcome inequality both within and between countries and contribute to the elimination of poverty.

- Greater accountability to people. Public and private actors at all levels with power to influence the outcomes of globalization must be democratically accountable for the policies they pursue and the actions they take. They should deliver on their commitments and use their power with respect for others.

Please use the following format when citing this chapter:

Rasmussen, L. B., Skarler, V, 2006, in IFIP International Federation for Information Processing, Volume 223, Social Informatics: An Information Society for All? In Remembrance of Rob Kling, eds. Berleur, J., Numinen, M. I., Impagliazzo, J., (Boston: Springer), pp. 483-486. 
- Deeper partnerships. A number of actors are engaged in the realisation of global social and economic aims - international organisations, governments and parliaments, business, labour, civil society and many others. Dialogue and partnership among them is an essential democratic instrument to create a better world.

- An effective United Nations. A stronger and more efficient multilateral system is the key instrument to create a democratic, legitimate and coherent framework for globalization (according to the report).'

Globalization is a complex phenomenon that has had a long reaching effect. And the term 'globalization' has acquired many emotive connotations and become a frequently contested issue in current political discourses. At one extreme, globalization is seen as an irresistible and good force delivering economic prosperity to people around the world, and at the other, it is blamed as a source of all contemporary ills.

Although, it is widely accepted that the key characteristics of globalization have been the liberalisation of international trade, the expansion of Foreign Direct Investments (FDI), and the emergence of massive cross-border financial flows. This has resulted in increasing competition on the global markets. It is also widely acknowledged that this has come about through combined effect of two underpinning factors namely; policy decisions to reduce national barriers to international economic transactions and the impact of new technology, especially in information and communication technology. These developments created the enabling conditions for the beginning of globalization. ${ }^{2}$

Globalization has set in motion a process of far-reaching change that is affecting everyone. New technology, supported by more open policies, has created a world more interconnected than ever before. This distance not only growing interdependence in economic relations regarding; trade, investments, finance and the organisation of production globally, but also social and political interactions among organisations and individuals around the world.

The effects of the new technology have also given a distinctive character to the current process of globalization, compared to similar episodes in the past. The natural barriers of time and space have been vastly reduced. The cost of moving information, people and goods and capital across the world has fallen dramatically, while global communication is cheap and instantaneous, and continuing ever more so. This has vastly expanded the feasibility of economic transactions across the globe, and markets can now be global in scope and encompass an expanding range of goods and services. Another distinctive subject of the current process of globalization relates to what is absent, and unlike earlier times of globalization that were characterised by massive cross-border movements of people, the current process largely excludes this.

Hopefully we all seek a globalization with social dimension, which sustains human values and enhances the well being of people, in terms of their freedom, prosperity and security. Globalization is seen through the eyes of women and men in terms of the opportunity it provides for decent work, for meeting their essential needs for food, water, health, education and shelter, and for a liveable environment. Without such a social dimension, many will continue to view globalization as a new 
version of earlier forms of domination and exploitation. The fundamentals of this social dimension include:

- A process of globalization based on universally shared values, which require all actors, including States, international organisations, business, labour, civil society and the media, to assume their individual responsibilities. It demands respect for obligations and duties under international law. It also requires economic development to be based on respect on human rights.

- An international commitment to ensure the basic material and other requirements of human dignity for all, enshrined in the Universal Declaration of Human Rights. The eradication of poverty and the attainment of the Millennium Development Goals (MDGs) should be seen as the first steps towards a socioeconomic 'floor' for the global economy. ${ }^{3}$

- A sustainable path of development, which provides opportunities for all, expands sustainable livelihoods and employment, promotes gender equality, and reduces disparities between countries and people. It calls for greater coherence between economic, social and environmental policies.

- A more democratic governance of globalization, which permits for greater voice and participation, and ensures accountability, while fully respecting the authority of institutions of representative democracy and the rule of law. ${ }^{4}$

The resources exist to overcome the most urgent problems of poverty, disease and education. Mahatma Gandhi put it very simply:

"There is enough in the world for everybody's need, but there cannot be enough for everybody's greed". 5

This report set out the broad goals and principles that can guide policy to handle more effectively with the social dimension of globalization, fully recognising that their implementation shall respond to the needs and specific conditions of each country. From this perspective it is clear that national governance have to improved in all countries, however more radically in some than in others, and there is wide international agreements on the fundamentals, which we all must strive for:

- Good political governance based on a democratic political system, respect for human rights, and the rule of law and social equity.

- An effective State that ensures high and stable economic growth, provides public goods and social protection, raises the capabilities of people through universal access to education and other social services, and promotes gender equity.

- A vibrant civil society empowered by freedom of association and expression, that reflects and voices the full diversity of views and interests. Organisations representing public interests, the poor and other disadvantaged groups are also fundamental for ensuring participatory and socially just governance.

- Strong representative organisations of workers and employers are essential for fruitful social dialogue. ${ }^{6}$

The proposals call for a wider and more democratic participation of people and countries in the creations of policies that affect them. They also require those with the capacity and power to decide: governments, parliaments, business, labour, civil society and international organisations, and to assume their common responsibility to promote a free, fair and productive global community. 
1 World Commission on the Social Dimension of Globalization, February 2004, Report: 'A Fair Globalization: Creating opportunities for all', Synopsis, pp. ix-x. Photocomposed by ILO, Geneva, Switzerland.

2 Ibid. pp. 24-25.

3 The Millennium Development Goals: In: September 2000, 189 Heads of State and Governments committed their countries - rich and poor - to meet a set of time-bound and measurable goals by 2015: eradicate extreme poverty and hunger, achieve universal primary education, promote gender equality and empower women, reduce child mortality, improve maternal health, combat HIV/AIDS, malaria and other diseases, ensure environmental sustainability, develop a global partnership for development. http://www.un.org/millenniumgoals/

4 World Commission on the Social Dimension of Globalization, doc. cit. p. 5. Photocomposed by ILO, Geneva, Switzerland

5 Ibid.

6 Ibid. p. xii. 